\title{
Finite Element Analysis of Concrete Bridge Slabs Reinforced with Fiber Reinforced Polymer Bars
}

\author{
S.E. El-Gamal \\ Department of Civil \& Architectural Engineering, Sultan Qaboos University, P.O. Box 33, Postal Code 123, Al-Khodh, \\ Muscat, Sultanate of Oman
}

Received 10 June 2014; accepted 11 September 2014

\begin{abstract}
Due to their non-corrosive nature, high strength and light weight, fiber reinforced polymers (FRP) are being widely used as reinforcement in concrete bridges, especially those in harsh environments. The current design methods of concrete deck slabs in most bridge design codes assume a flexural behavior under traffic wheel loads. The load carrying capacities of concrete bridge deck slabs, however, are greatly enhanced due to the arching action effect developed by lateral restraints. This study presents the results of a non-linear finite element (FE) investigation that predicts the performance of FRP reinforced concrete (RC) deck slabs. The FE investigation is divided into two main parts: a calibration study and a parametric study. In the calibration study, the validity and accuracy of the FE model were verified against experimental test results of concrete slabs reinforced with glass and carbon FRP bars. In the parametric study, the effect of some key parameters influencing the performance of FRP-RC deck slabs bars was investigated. These parameters include the FRP reinforcement ratio, concrete compressive strength, slab thickness and span-to-depth ratio.
\end{abstract}

Keywords: Finite element analysis, Concrete, Bridge deck slabs, Fiber reinforced polymers, Reinforcement ratio, Compressive strength, Span to depth ratio.

استخدام طريقة العناصر المحدودة لدراسة بلاطات الجسور الخرسانية المسلحة بقضبان ألياف

$$
\text { شريف س. الجمل البوليمر المقوى }
$$

الملخص: نظرا لطبيعتها غير القابلة للصدأ وقوتها العالية وخفة وزنها ، فإن ألياف البوليمر المقوى تستخدم على نطاق واسـع ِِّْ تسليح

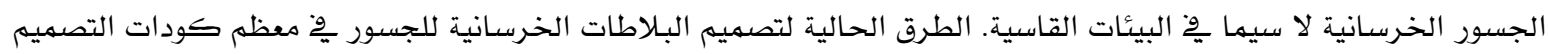
تقترض سلوك الانحناء تحت تأثير أحمال عجلات السيارات. لكن قدرة تحمل بلاطات الجسور الخرسانية أقوى بكثير بسبب

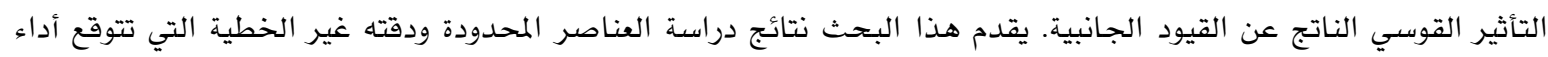
بلاطات الجسور الخرسـانية المسلحة بواسطة ألياف البوليمر المقوى. تتقسم الدراسة إلى قسميسن رئيسين: معايرة البرنامج المستخدم ثم دراسة لبعض العوامل المهمة. پِّ دراسـة المعايرة، تم التحقق من صحة نهوذج العناصر المحدودة بهقارنته بنتائج اختبارات تجريبية

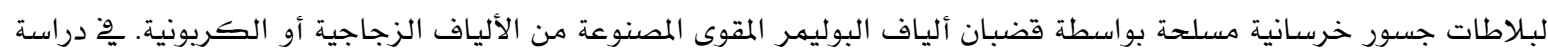

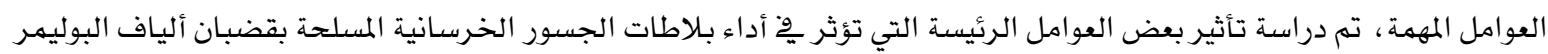
المقوى. وتشهمل هذه العوامل نسبة التسليح، قوة الخرسانة ، وسمك البلاطة ، ونسبة عرض البلاطة إلى العهق.

مفاتيح الكلمات: دراسة العناصر المحدودة ، خرسانة ، بلاطات الجسور، ألياف البوليمر المقوى ، نسبة التسليح , قوة الخرسانة ، سمك البـلاطة ، نسبة عرض البلاطة إلى العمق.

Corresponding author's e-mail: sherif@squ.edu.om 


\section{Introduction}

One of the most common bridge designs used for highway reinforced concrete (RC) bridges is the slab-on-girder type. This type consists of a RC slab supported on a number of parallel longitudinal girders. Different design codes (CAN/CSA 2006; AASHTO 1996) specify the flexural design method for designing RC deck slabs. Different experimental investigations and theoretical studies, however, have concluded that, when subjected to wheel loads, punching shear is the failure mode of restrained bridge deck slabs having a certain range of span/depth ratio. Many researchers have reported that the punching strength of a concrete slab could be greatly enhanced by the arching action that results when its edges are restrained against movement. The magnitude of strength enhancement depends on the degree of lateral restraint; the stiffer the lateral restraint the greater the enhancement (Fang et al. 1990; Graddy et al. 2002; Hewitt and Batchelor 1975). Consequently, the Canadian Highway Bridge Design Code (CHBDC) (CAN/CSA-S6, 2006) allows under some conditions the use of an empirical method to design concrete deck slabs supported on girders. This method requires four layers of steel reinforcement with two at the top and two at the bottom. Each layer has a steel reinforcement ratio of only $0.3 \%$.

The corrosion of steel reinforcement has typically led to significant deterioration and rehabilitation needs for RC structures in harsh environmental conditions. Concrete bridge deck slabs are one of the main bridge components that rapidly deteriorate due to direct exposure to de-icing salts and the traffic environment. Fiber reinforced polymer (FRP) bars, with their corrosion resistance, light weight and high strength are a promising alternative to traditional steel reinforcement in bridge deck slabs (El-Gamal et al. 2004; Bouguerra et al. 2011; Alsayed et al. 2012). Due to the increased use of FRP bars, especially in bridges, the CHBDC allows their use in barriers, beams and slabs. However, the behavior of FRP-RC deck slabs has not been fully explored and the current design of such slabs is still based on tests of deck slabs reinforced with steel. Therefore, research studies and investigations on the behavior of such deck slabs are needed.
An extensive experimental study has been carried out by the author to investigate the performance of deck slabs reinforced with several types and ratios of FRP composite bars. Although accurate and reliable results can be obtained from experimental tests, they are limited, expensive and time consuming. Therefore, the finite element (FE) method is an attractive alternative method.

This paper presents the results of a FE study that investigates the performance of FRP-RC bridge deck slabs. The FE investigation is divided into a calibration study and a parametric study. The validity and accuracy of the FE model were verified against the experimental test results of two full scale concrete deck slabs reinforced with glass and carbon FRP bars. In the parametric study, the effect of some key parameters that influence the behavior of bridge deck slabs reinforced with glass fiber reinforced polymer (GFRP) bars was investigated. These parameters include FRP reinforcement ratio, concrete compressive strength, slab thickness and span-to-depth ratio.

\section{Finite Element (FE) Modeling}

\subsection{Program Capabilities}

FE modeling was conducted using the ANATECH Concrete Analysis Program, Version 3.0 (ANATECH Corp., San Diego, California, USA). The concrete material model was based on a smeared cracking methodology which states that when a crack occurs, the stress normal to the crack direction decreases to zero, resulting in redistribution of stresses around the crack. Cracks are allowed to form in three directions and, once a crack forms, it may close and re-open but it cannot heal. The model includes residual tension stiffening algorithms for the gradual transfer of load to reinforcement during crack formation and for shear retention to simulate the effect of crack roughness through aggregate interlocking (Mohamed and Rizkalla 1999). The program accounts for the shear stiffness reduction due to cracking and also considers further decay as the crack opens. The program models the reinforcement as individual sub-elements within the concrete elements. The anchorage loss is modeled as an effective stiffness degradation of the rebar as a function 
of the concrete strain normal to the rebar. More details about the program can be found in the ANACAP Concrete Analysis Program Theory Manual (James 2004).

\subsection{Validation of the Model}

\subsubsection{Description of Test Specimens}

The finite element model (FEM) was calibrated using experimental tests conducted by the author (El-Gamal 2005). Through this program, several full scale bridge deck slabs $(3,000 \mathrm{~mm}$ long $\times 2,500 \mathrm{~mm}$ wide $\times 200 \mathrm{~mm}$ deep) were constructed and tested. Different types and ratios of FRP bars were used in the slabs. The test results of two slabs were used for validation of the FEM. The two slabs contained identical GFRP reinforcement in all directions (No.16 @ 200 mm) except in the bottom short direction where one slab (GFRP) was reinforced with No.19 $\left(\mathrm{d}_{\mathrm{b}}=19 \mathrm{~mm}\right)$ GFRP bars and the other slab (CFRP) was reinforced with No.10 $\left(\mathrm{d}_{b}=9.5\right.$ $\mathrm{mm})$ CFRP bars. Table 1 shows the reinforcement details and concrete compressive strength of the two slabs. The slabs were constructed using a ready-mixed concrete with an average 28-day concrete compressive strength of $45 \mathrm{MPa}$. Sand-coated glass and carbon FRP bars were used. The mechanical properties of the bars were determined by performing tensile tests on FRP specimens according to ACI440 (2006). The properties of the bars used are listed in Table 2. The slabs were tested under a concentrated load with an area of $600 \mathrm{~mm} \times 250 \mathrm{~mm}$ to represent the foot print of a truck wheel (CL-625 truck, as specified by clause 3.8.3.1 in the CHBDC) acting on the center of the slab. The slabs were supported on steel girders using steel bolts. Steel angles were used to prevent the lateral movement of the girders (Fig. 1). More details about test specimens, instrumentation and test set-up can be found in (El-Gamal 2005; El-Gamal et al. 2005a, 2007).

\subsubsection{Description of the Finite Element Model (FEM)}

Due to symmetry, one-quarter of the slab and supporting elements was modeled. The slab thickness was divided into three unequal thickness layers. The thicknesses of the layers were selected to produce a finer mesh in the compression zone near the top surface of the slab. A finer mesh with smaller element sizes was also used within the loading area (Fig. 2).

Twenty-node iso-parametric brick elements were used to model the supporting steel girders, concrete slab and top steel channel. The cross frames were modeled using spring element with stiffness equal to the axial stiffness of the steel angles. Reinforcing bars and steel bolts were modeled using embedded bar elements. The load was applied as a distributed load over the loaded area incrementally. Figure 3 shows the finite element mesh and reinforcement of one quarter of the deck slab. At the expected cracking and failure load levels, small load increments were used to increase the accuracy of the analysis and to closely capture the behavior.

In addition to the material properties of concrete and reinforcing bars given before, the modulus of elasticity and cracking strength of concrete was calculated using Eq. 1 and 2, respectively.

$$
\begin{aligned}
& E_{c}=\left(3000 \sqrt{f_{c}^{\prime}}+6900\right)\left(\gamma_{c} / 2300\right)^{1.5} \\
& (\mathrm{CAN} / \mathrm{CSA}-\mathrm{S6} 2006)
\end{aligned}
$$

$f_{r}=0.4 \sqrt{f_{c}^{\prime}}$

- Poission's ratio of concrete, $v_{c}$, was assumed to be 0.2 .

- Poission's ratio of steel, $v_{\mathrm{s}}$, was assumed to be 0.3 .

- Poission's ratio of FRP bars, $v_{\mathrm{FRP}}$, was assumed to be 0.25 .

\subsection{Comparison between the FEM Model and Experimental Results}

Table 3 summarizes the predicted cracking and failure loads, deflections and reinforcement strains using the FEM compared to the experimental results of the two deck slabs (CFRP and GFRP). It can be noticed that the FEM predicted well the cracking and punching failure loads, load-deflection behavior and loadstrain behavior.

The two FRP-reinforced deck slabs failed in punching shear. At failure, the concrete compressive strain at a distance of $D / 2+y$ from the center of the loaded area reached a value of 1,900 micro-strains, where $D$ is the diameter of the idealized load area which is defined as a 
circle that has the same perimeter as the rectangular loaded area, $y$ is defined as the location of the center of rotation of concrete wedges, causing punching which is approximately 0.1 of the thickness of the slab measured from the center of the load (Hassan et al. 2004). This distance and strain level $(1,900$ micro-strains) have been considered by several researchers (Kinnunen and Nylander 1960; Mufti and Newhook 1998; Mohamed and Rizkalla 1999; Hassan et al. 2004) as an indication of failure due to concrete crushing, which results in punching shear failure.

Table 1. Details of slab reinforcement and concrete compressive strength.

\begin{tabular}{|c|c|c|c|c|c|}
\hline \multirow[b]{2}{*}{ Slab } & \multirow{2}{*}{$\begin{array}{c}f_{c}^{\prime} \\
(\mathrm{MPa})\end{array}$} & \multirow{2}{*}{$\begin{array}{c}\rho_{\text {act }}(\%) \\
\text { of bottom } \\
\text { main rein. }\end{array}$} & \multirow{2}{*}{$\begin{array}{c}\text { Axial stiffness } \\
\left(\rho_{\text {act }} \times E\right) \\
\left(\mathrm{N} / \mathbf{m m}^{2}\right)\end{array}$} & \multicolumn{2}{|c|}{ Reinforcement configuration } \\
\hline & & & & Bottom short (main) & All other directions \\
\hline GFRP & 49.1 & 1.2 & 528 & No.19@150 mm & No.16@200 mm \\
\hline CFRP & 49.6 & 0.34 & 415 & No.10@125 mm & No.16@200 mm \\
\hline
\end{tabular}

Table 2. The mechanical properties of the fiber reinforced polymer (FRP) bars.

\begin{tabular}{ccccccc}
\hline Bar Type & $\begin{array}{c}\text { Diameter } \\
\mathbf{( m m )}\end{array}$ & $\begin{array}{c}\text { Area } \\
\left.\mathbf{( m m}^{\mathbf{2}}\right)\end{array}$ & $\begin{array}{c}\text { Modulus of } \\
\text { Elasticity } \\
\mathbf{( G P a )}\end{array}$ & $\begin{array}{c}\text { Tensile Strength } \\
\mathbf{( M P a )}\end{array}$ & $\begin{array}{c}\text { Ultimate Strain } \\
\mathbf{( \% )}\end{array}$ \\
\hline \multirow{2}{*}{ GFRP } & No. 16 & 15.9 & 198.6 & $44.6 \pm 0.8$ & $727 \pm 9[700]^{+}$ & $1.65 \pm 0.03[1.56]^{!}$ \\
& No. 19 & 19.0 & 283 & $44.5 \pm 1.3$ & $637 \pm 15[592]^{+}$ & $1.37 \pm 0.03[1.28] !$ \\
\hline \multirow{2}{*}{ CFRP } & No. 10 & 9.5 & 71.0 & $122 \pm 2.4$ & $1444 \pm 18.0[1390]^{+}$ & $1.23 \pm 0.07[1.02] !$ \\
\hline
\end{tabular}

${ }^{+}$Guaranteed tensile strength $=$average tensile strength minus three times the standard deviation

!Guaranteed tensile strain $=$ average tensile strain minus three times the standard deviation

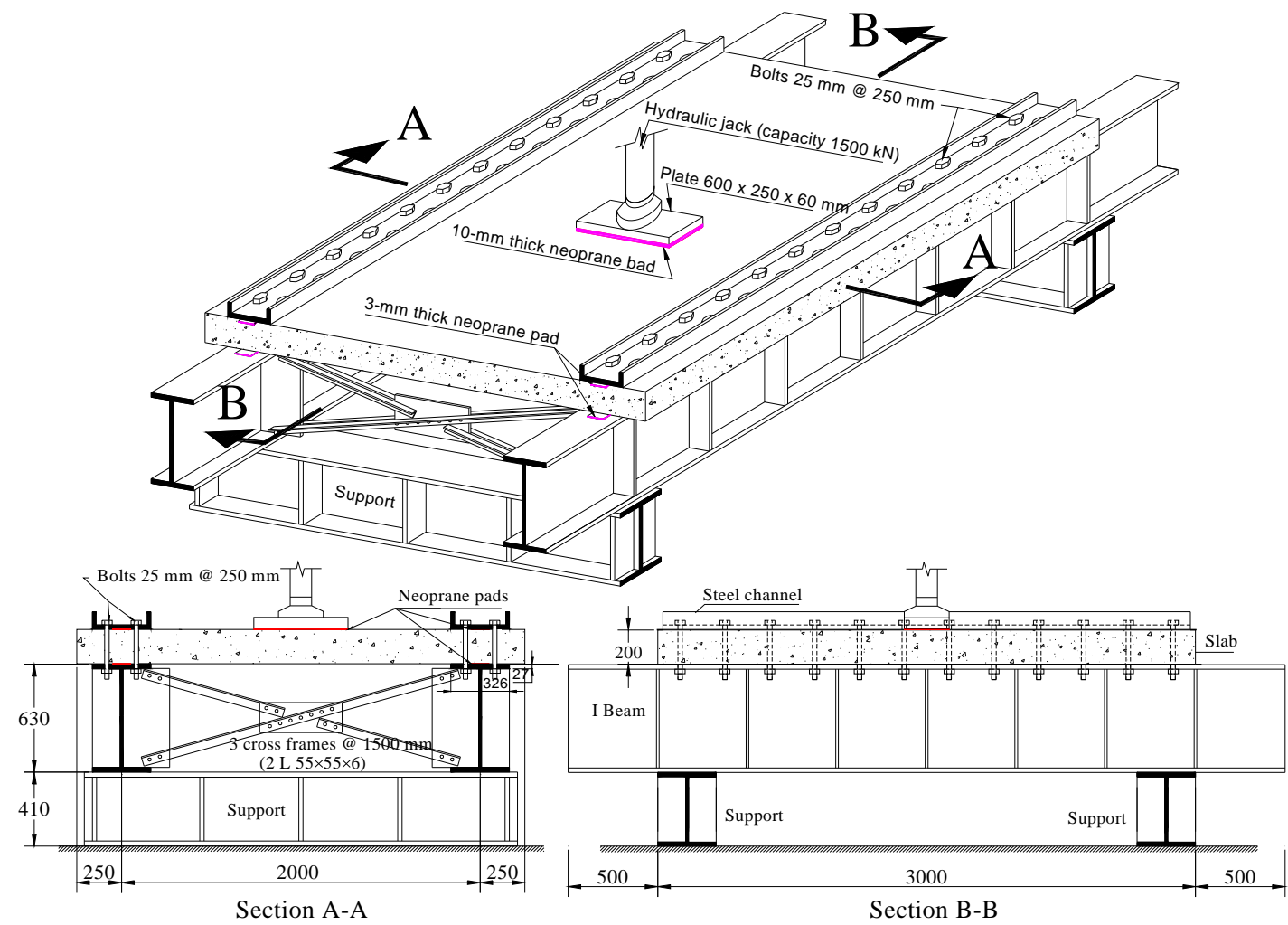

Figure 1. Test Set-up (El-Gamal 2005). 


\subsubsection{Cracking and Failure Loads}

The cracking and failure load predictions from the FEM compared to the experimental measures of the two deck slabs are shown in Table 3. It shows that the FEA predicted with high accuracy $(>96 \%)$ the cracking load of the two deck slabs. The predicted failure loads were 675 and $695 \mathrm{kN}$ for CFRP and GFRP slabs, respectively. This indicates that the FEM predicted with good accuracy (95 and 100.7\%) the punching capacity of the two deck slabs.
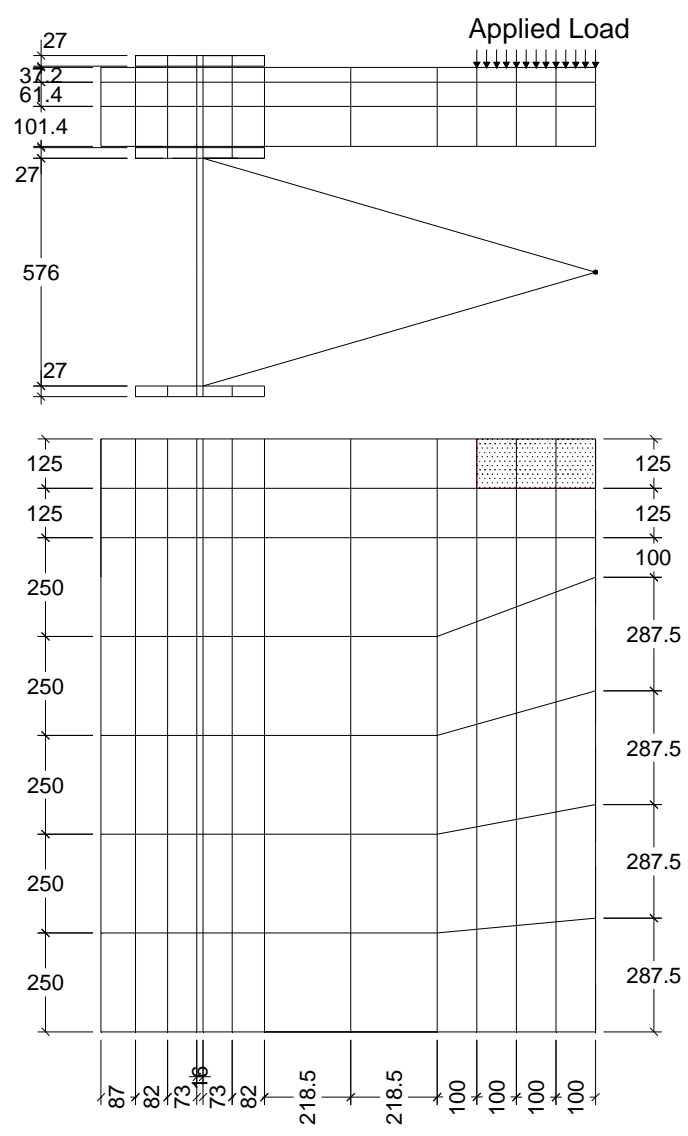

Figure 2. Mesh dimensions using a threedimensional 20-node brick element model.

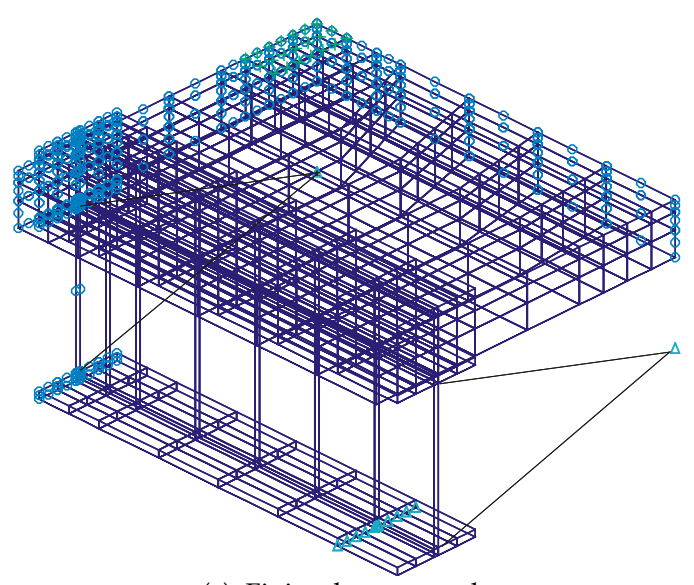

(a) Finite element mesh

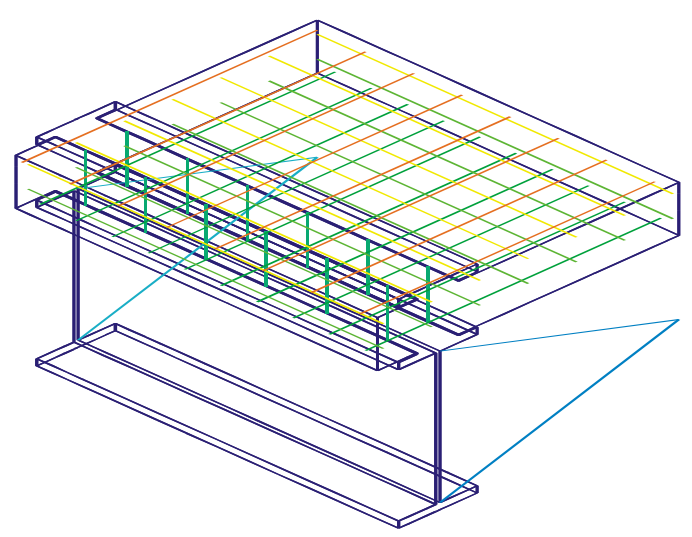

(b) Model showing the reinforcement

Figure 3. The finite element model (FEM) of one quarter of the slab and the set-up.

\subsubsection{Load-Deflection and Strains Relationships}

Figures 4 and 5 show the plots of load versus deflection, reinforcement strains and concrete strains from the FEM compared with the experimental results. Good agreement can be noted between the obtained FE predictions and experimental results for deflection and strains. Before cracking, the FEA predictions were slightly lower than those from the experimental tests.

Table 3. Summary of experimental and FEA results.

\begin{tabular}{|c|c|c|c|c|c|c|c|c|c|c|c|c|}
\hline \multirow{3}{*}{ Slab } & \multirow{2}{*}{\multicolumn{2}{|c|}{$\begin{array}{l}\text { Cracking } \\
\text { Load (kN) }\end{array}$}} & \multirow{2}{*}{\multicolumn{2}{|c|}{$\begin{array}{l}\text { Failure } \\
\operatorname{load}(\mathbf{k N})\end{array}$}} & \multicolumn{4}{|c|}{$\begin{array}{l}\text { Max. deflection } \\
(\mathrm{mm})\end{array}$} & \multicolumn{4}{|c|}{$\begin{array}{c}\text { Max. strains in } \\
\text { reinforcement (micro-strain) }\end{array}$} \\
\hline & & & & & \multicolumn{2}{|c|}{$\begin{array}{l}\text { Ultimate design } \\
\text { load }(208.25 \mathrm{kN})\end{array}$} & \multicolumn{2}{|c|}{ Failure } & \multicolumn{2}{|c|}{$\begin{array}{l}\text { Ultimate design } \\
\text { load }(208.25 \mathrm{kN})\end{array}$} & \multicolumn{2}{|c|}{ Failure } \\
\hline & Exp & FEA & Exp & FEA & Exp & FEA & Exp & FEA & Exp & FEA & Exp & FEA \\
\hline CFRP & 115 & 115 & 674 & 679 & 3.67 & 3.62 & 22.60 & 22.87 & 2367 & 2651 & 8500 & 8210 \\
\hline GFRP & 115 & 115 & 732 & 695 & 3.47 & 3.69 & 21.20 & 21.41 & 2270 & 2168 & 8080 & 7458 \\
\hline
\end{tabular}


This may be attributed to the existence of some micro cracks in the slabs due to concrete shrinkage, which can reduce the stiffness of the slabs. However, after cracking until failure, the FEM predictions matched the test results very well.

For the CFRP-RC deck slab, the maximum predicted deflection at factored design load (206.25 kN according to the CHBDC) and at failure were 3.67 and $22.87 \mathrm{~mm}$, respectively, which were about $99 \%$ and $101 \%$ of the measured values (3.62 and $22.6 \mathrm{~mm})$, respectively. The maximum predicted reinforcement strains were 2,651 and 8,210

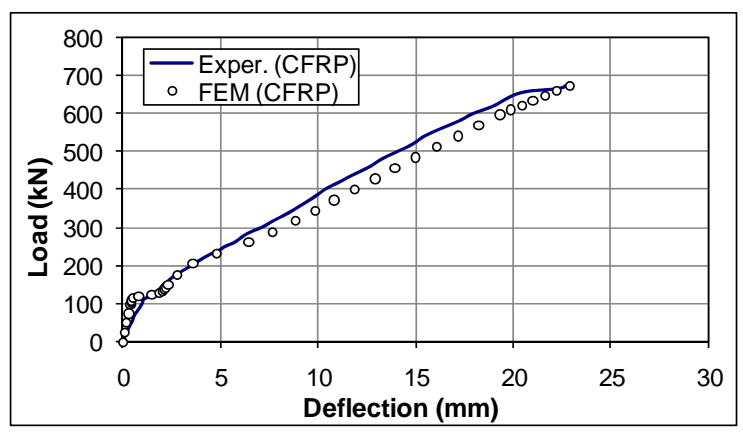

(a) Load-maximum deflection.

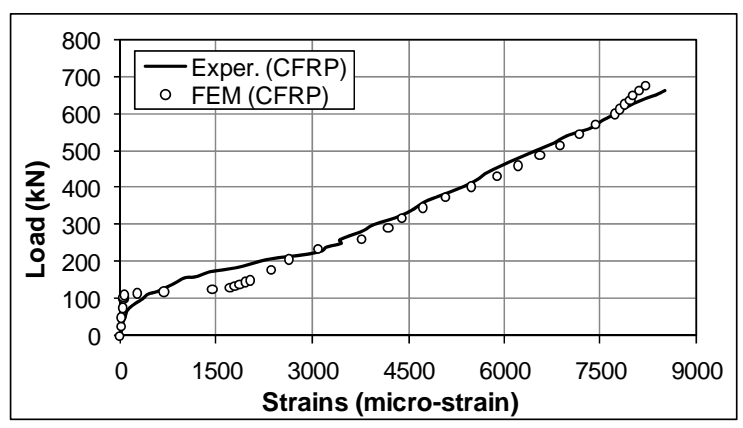

(b) Load-max. reinforcement strains.

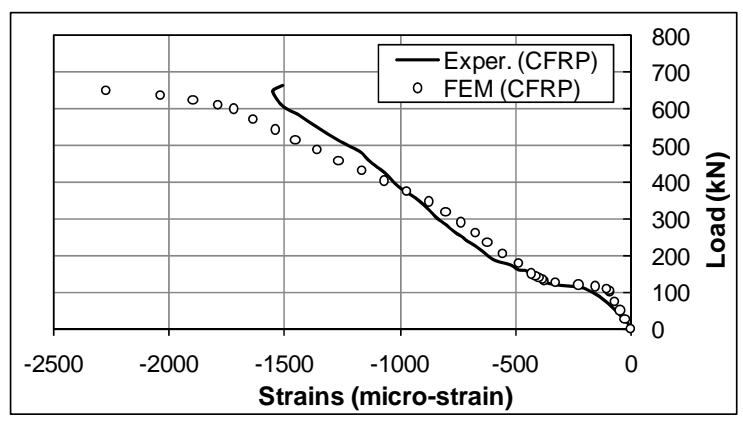

(c) Load-maximum concrete strains.

Figure 4. Comparison of FEM and experimental results of the CFRP-reinforced slab. micro-strains at factored design load and at failure, respectively, which were about $111 \%$ and $97 \%$ of the measured values $(2,367$ and 8,500 micro-strains). For the GFRP-RC deck slab, the maximum predicted deflection at the factored design load and at failure were 3.69 and 21.41 $\mathrm{mm}$, respectively, which were about $106 \%$ and $101 \%$ of the measured values (3.47 and 21.2 $\mathrm{mm})$, respectively. The maximum predicted reinforcement strains were 2,161 and 7,458 micro-strains at the factored design load and at failure, respectively, which were about $96 \%$ and $93 \%$ of the measured strain values $(2,270$ and 8,080 micro-strains).

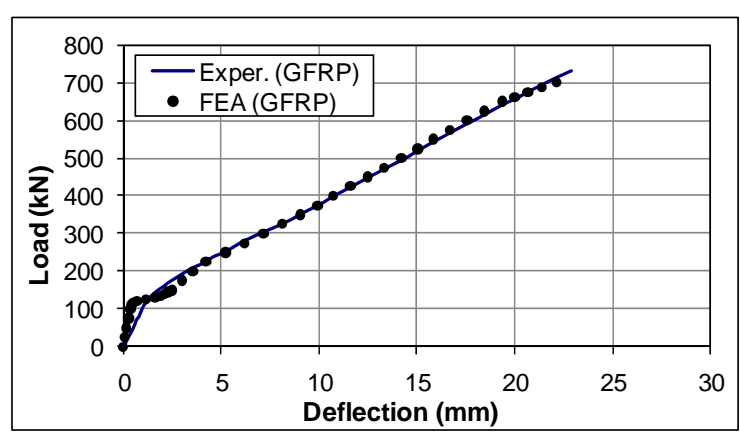

(a) Load-maximum deflection.

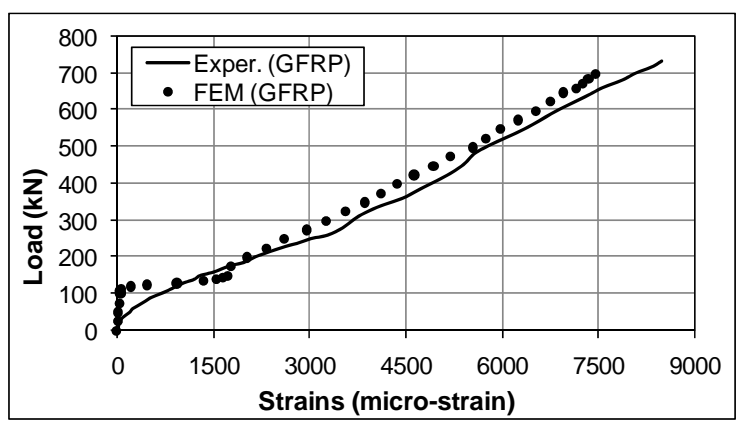

(b) Load-max. reinforcement strains.

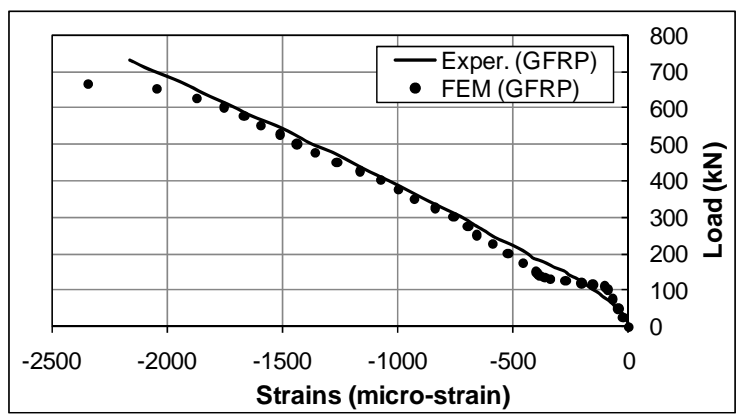

(c) Load-maximum concrete strains.

Figure 5. Comparison of FEM and experimental results of the GFRP-reinforced slab. 


\subsubsection{Cracks Propagation}

The crack propagations at different load levels are shown in Fig. 6. The figure shows that the predictions from the FEM match the behavior from the experimental tests. The predictions show that the first cracks occurred under the load and propagated longitudinally (Fig. 6a). By increasing the load, other cracks propagated in the radial direction (Fig. 6b). On the top face of the slabs, the first crack occurred above the supporting beams at high load levels (about $480 \mathrm{kN}$ ) (Fig.6c). At failure, all the bottom surface of the deck slabs cracked, especially under the loaded area, which is evidence of punching failure [Fig. 6d]. These cracking propagation stages were in close agreement with that obtained from the experimental test.

\section{Parametric Study}

Following the verification of the FEM, the developed model was used to study the effect of key parameters that influence the behavior of FRP-RC bridge deck slabs. These parameters included the FRP reinforcement ratio, concrete compressive strength, slab thickness and spanto-depth ratio.

\subsection{FRP Reinforcement Ratio}

Among the different types of FRP bars, glass FRP composite bars have recently drawn much attention as reinforcement for concrete infrastructures due to their low cost compared to the other available types (carbon and aramid) allowing their wide use in bridge deck slabs. The experimentally tested slab GFRP (second slab in Table 3), was considered a reference specimen for FEMs. The concrete dimensions, concrete covers, boundary and loading conditions were kept unchanged. The only parameter was the GFRP reinforcement ratio in different directions. Five different reinforcement configurations were investigated in this study (Table 4).

\subsubsection{Effect of Bottom Transverse Reinforcement}

Three different reinforcement ratios for the bottom transverse reinforcement were investigated as shown in Table 4 (Cases 1, 2 and 3 ). The three cases have the same reinforcement in all directions $(0.6 \%)$ except in the main bottom direction, which has three different reinforcement ratios $(1.2 \%, 0.9 \%$ and $0.6 \%)$. The first case represents almost the same bottom transverse reinforcement specified by the CHBDC (CAN/CSA 2006). Cases 2 and 3 represent lower bottom transverse reinforcement ratios.

The predicted load-deflection curves of the three slabs are shown in Fig. 7a. The predicted deflection at service load level ranged between 0.4 and $0.44 \mathrm{~mm}$, which is well below the allowable code limits (span/800). The maximum predicted deflections at failure were 21.3, 25.5 and $27.45 \mathrm{~mm}$ for cases 1, 2 and 3, respectively. This means that decreasing the reinforcement ratio of the main bottom reinforcement to half increased the maximum deflection by about $9 \%$ and $22 \%$ at service and ultimate load, respectively.

The predicted load-maximum reinforcement strains in all three cases are shown in Fig. $7 b$. The predicted reinforcement strains at service load were 215, 329 and 398 micro-strains for cases 1, 2 and 3, respectively. At failure, these strains were $7,538,8,444$ and 10,930 microstrains, respectively. This means that the maximum strains increased by about $85 \%$ and $45 \%$ at service and ultimate load, respectively, when the bottom transverse reinforcement was decreased to half. This indicates that the bottom transverse reinforcement ratio had a significant effect on the FRP reinforcement strains. Thus, decreasing the bottom main reinforcement ratio by $1.2 \%$, which is allowed by the CHBDC, is not recommended until approved under different spans and loading conditions.

All the slabs failed by concrete crushing resulting in punching shear. The ultimate load values were 692, 687 and $674 \mathrm{kN}$ for cases 1, 2 and 3 , respectively, which indicates that the punching capacity decreased by about $2.6 \%$ as a result of decreasing the main bottom reinforcement by $50 \%$. This indicates that the bottom main reinforcement had an insignificant effect on the punching capacity of FRP-RC bridge deck slabs.

\subsubsection{Effect of Top Reinforcement}

Three different reinforcement ratios for the top reinforcement in both directions were investigated as listed in Table 4 (cases 1, 4 and 5). 
Table 4. Slab configurations (effect of reinforcement ratio).

\begin{tabular}{|c|c|c|c|}
\hline \multirow{2}{*}{$\begin{array}{l}\text { Case } \\
\text { No. }\end{array}$} & \multicolumn{2}{|c|}{ Bottom reinforcement } & \multirow{2}{*}{$\begin{array}{l}\text { Top reinforcement } \\
\text { (both directions) }\end{array}$} \\
\hline & Transverse & Longitudinal & \\
\hline 1 & No. 19@150 mm (1.2\%) & \multirow{3}{*}{ No.16@200 mm (0.6\%) } & \multirow{3}{*}{ No.16@200 mm (0.6\%) } \\
\hline 2 & No.19@200 mm (0.9\%) & & \\
\hline 3 & No.16@200 mm (0.6\%) & & \\
\hline 4 & \multirow{2}{*}{ No. 19@150 mm (1.2\%) } & \multirow{2}{*}{ No.16@200 mm (0.6\%) } & No. 12@200 mm (0.36\%) \\
\hline 5 & & & - ------ $\quad(0.00 \%)$ \\
\hline
\end{tabular}

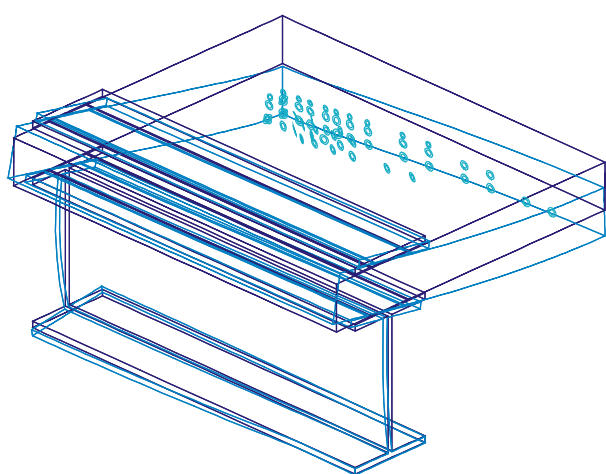

(a) Just after cracking $(120 \mathrm{kN})$.

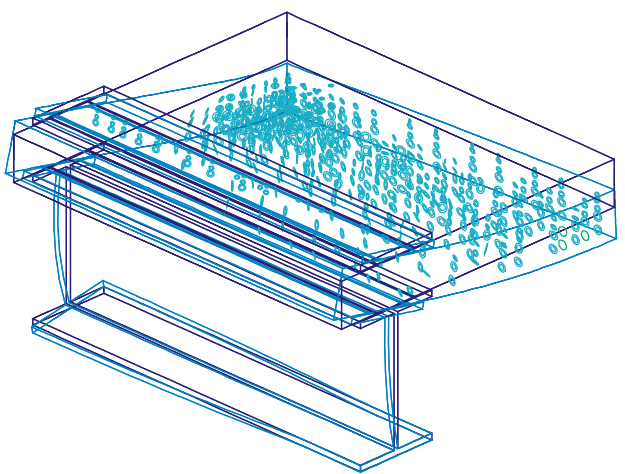

(c) At $480 \mathrm{kN}$.

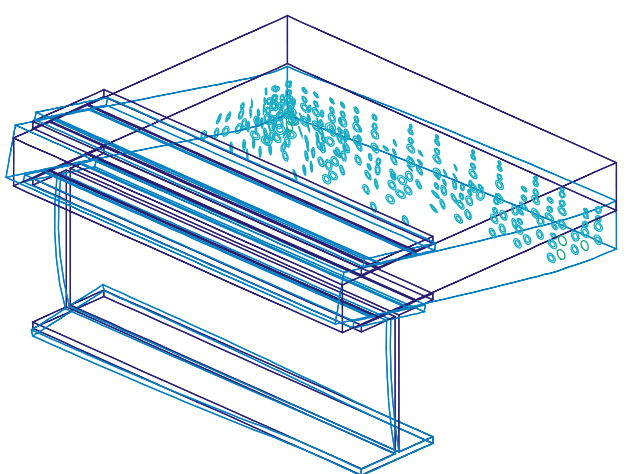

(b) At $220 \mathrm{kN}$.

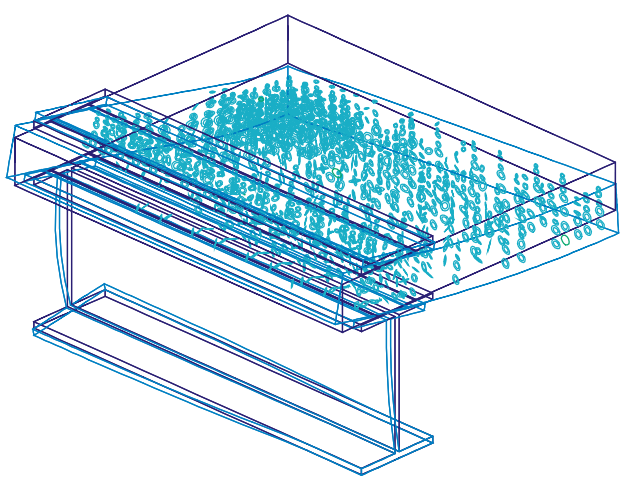

(d) At failure load $(695 \mathrm{kN})$.

Figure 6. Typical crack propagation for FRP-RC deck slabs (GFRP slab).

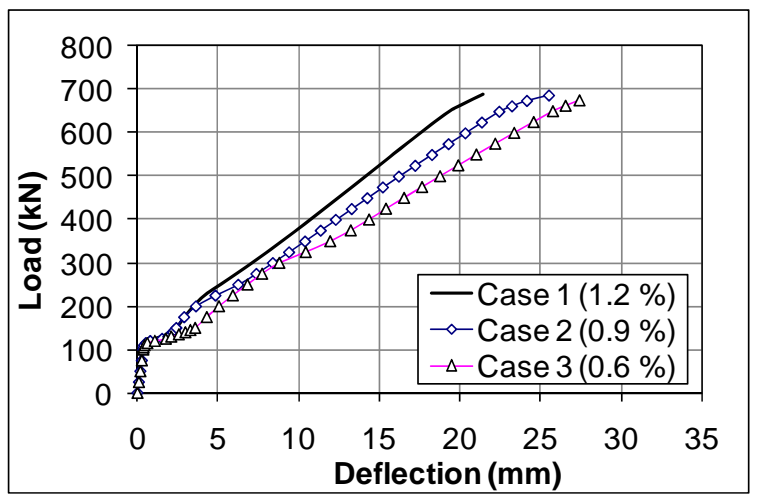

(a) Load-maximum deflection.

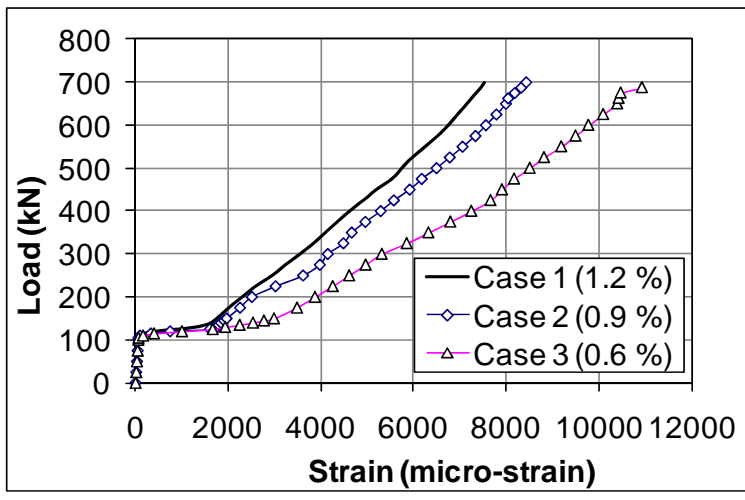

(b) Load-maximum reinforcement strains.

Figure 7. The effect of bottom transverse reinforcement. 


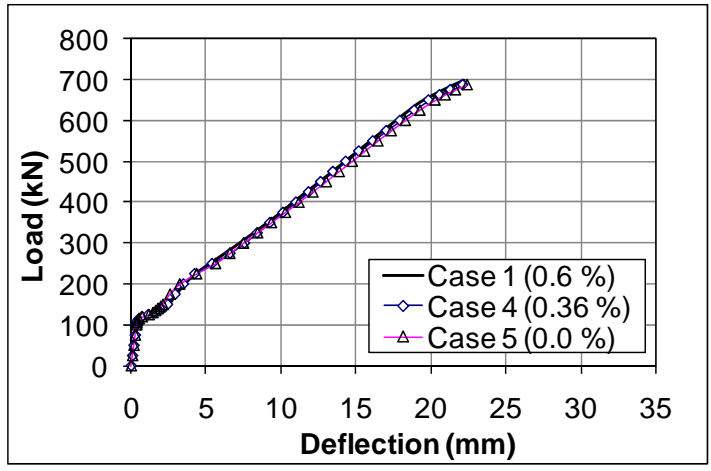

(a) Load-maximum deflection.

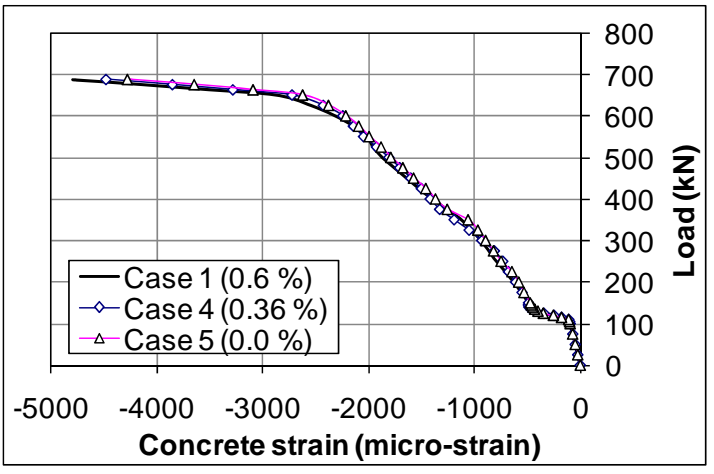

(b) Load-maximum concrete compressive strains.

Figure 8. Effect of top reinforcement

The top reinforcement in both directions had three different reinforcement ratios of $0.6 \%$, $0.34 \%$ and $0.0 \%$ for cases 1,4 and 5 , respectively. The predicted load-deflection curves and loadmaximum compressive concrete strains under the loaded area of the three slabs are shown in Fig. 8. The three slabs gave almost the same behavior. All the slabs failed in punching shear failure. The concrete compressive strains under the loaded area reached 4,700 micro-strains which were $55 \%$ higher than the maximum compressive strain of concrete. This can be related to concrete confinement under the loaded area. The ultimate load values were 693, 684.5 and $679.5 \mathrm{kN}$ for cases 1, 4 and 5, respectively, which indicates that without top reinforcement, the punching capacity decreased by only $0.6 \%$. This means that the top reinforcement had almost no effect on the overall behavior of restrained FRP-RC bridge deck slabs.

\subsection{Concrete Compressive Strength}

Concrete compressive strength is a major factor, if not the most important, in all punching shear code equations and design provisions. Most of the punching shear code equations (ACI 318-08 2008; CSA-A23.3 1994; JSCE 1997; ElGamal et al. 2005b) are based on the assumption that the punching shear is proportional to the square root of concrete compressive strength. Other codes and design provisions (BS8110 1997) assume that the punching shear is proportional to the cubic root of concrete compressive strength rather than the square root. In addition, these code equations are based on the test results of slabs made with relatively low compressive strength, varying mostly from 14 to $40 \mathrm{MPa}$ (Marzouk and Hussien 1991). To investigate the effect of concrete compressive strength on the behavior of GFRP-RC deck slabs, different concrete compressive strengths were investigated. The dimensions, concrete covers, reinforcement and boundary and loading conditions were kept unchanged as in the GFRP slab. Only the concrete strength was changed from 20 to 80 $\mathrm{MPa}$ (in increments of $10 \mathrm{MPa}$ ), consequently, the modulus of elasticity and cracking strength of concrete were changed and calculated using Eqs. 1 and 2, respectively.

\subsubsection{Deflection and Cracking Behavior}

The load-deflection behavior using different concrete compressive strengths is given in Fig. 9a. Increasing the concrete compressive strength increased the cracking load, which was $85 \mathrm{kN}$ for the slab with a concrete compressive strength of $20 \mathrm{MPa}$. It increased by 30\%, 52\% and $88 \%$ when the concrete strengths increased to 40,60 and $80 \mathrm{MPa}$, respectively. After cracking, linear deflection behavior continued until failure. All the load-deflection curves had the same slope; however, increasing the concrete strength decreased the deflections as a result of different cracking loads. At the factored design load, the predicted deflections were 6.49, 4.73, 3.5 and $2.37 \mathrm{~mm}$ for slabs with concrete compressive strengths of 20, 40, 60 and $80 \mathrm{MPa}$.

\subsubsection{Reinforcement Strains}

The predicted curves of load-maximum bottom transverse reinforcement strains for different concrete compressive strengths are 
shown in Fig. 9b. It can be noticed that increasing the concrete compressive strength decreased the predicted reinforcement strains before cracking. A sudden increase in the reinforcement strains was noted just after cracking and then the slabs behaved linearly up to failure. All the slabs had almost similar reinforcement strains after cracking. At the factored design load of $208.25 \mathrm{kN}$, the maximum predicted reinforcement strains were 2,515, $2,485,2,977$ and 2,289 micro-strains for slabs with concrete strengths of 20, 40, 60 and $80 \mathrm{MPa}$, respectively. This indicates that the maximum reinforcement strains at the factored design load decreased by about $5.3 \%, 10 \%$ and $16.4 \%$ when the concrete compressive strength increased to 40, 60 and $80 \mathrm{MPa}$. At a load level of $445 \mathrm{kN}$ (the failure load of the slab with the minimum concrete compressive strength of $20 \mathrm{MPa}$ ), the maximum predicted reinforcement strains were 5,530, 5,365, 5,484 and 5,671 micro-strains (almost equal values) for slabs with concrete strengths of 20, 40, 60 and $80 \mathrm{MPa}$, respectively. Therefore, it can be concluded that the concrete compressive strength has some effect on the bottom transverse reinforcement strains before cracking; however, after cracking it has an insignificant effect.

\subsubsection{Failure Load}

The effect of concrete compressive strength on the punching shear capacity is illustrated in Fig. 9c. The punching capacity increased by increasing the concrete strength. The failure load was found to be $445 \mathrm{kN}$ for the slab with a concrete strength of $20 \mathrm{MPa}$. It can be noted that the values of the failure loads increased by about $39 \%, 75 \%$ and $95 \%$ when the concrete strength was increased to 40,60 and $80 \mathrm{MPa}$, respectively. The failure loads did not increase linearly with respect to the concrete strength. The trend line of the results in Fig. 9c shows that the punching capacity is proportional to the square root of the concrete compressive strength as concluded by the North American codes.

\subsection{Deck Slab Thickness}

The effective depth of the concrete slab and, consequently, the slab thickness is a major factor that affects the punching capacity. All current design codes (ACI 318-08 2008; CSA-A23.3 1994; JSCE 1997; BS8110 1997) take into account the effect of slab thickness on the punching shear capacity. In order to investigate the effect of deck thickness on the behavior of FRP-RC bridge deck slabs, five thicknesses were used $(150,175,200,225$ and $250 \mathrm{~mm})$. All the slabs had $2000 \mathrm{~mm}$ span. The thicknesses studied provided a span/depth ratio ranging between 8 and 13.3.

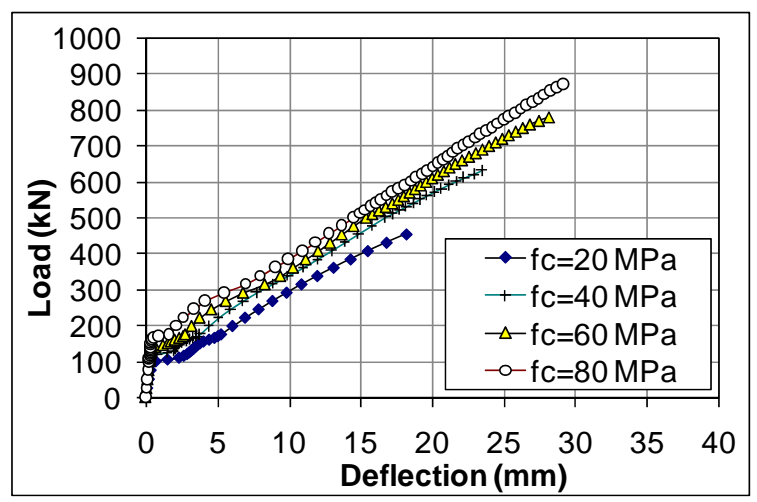

(a) Load-maximum deflection.

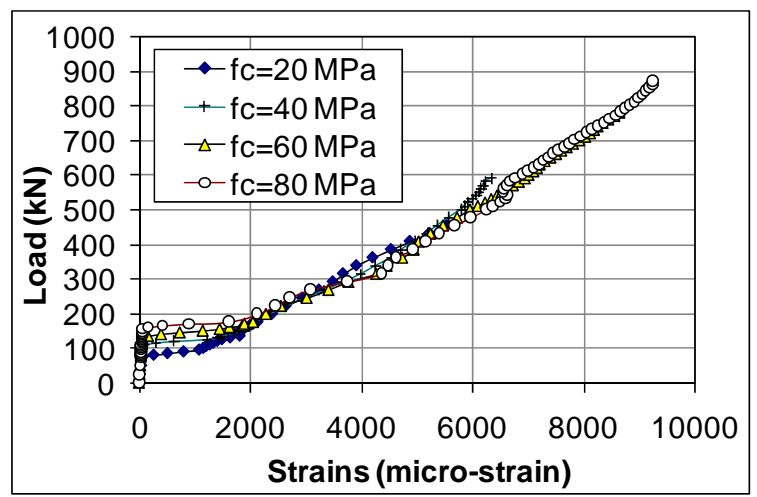

(a) Load-maximum reinforcement strains.

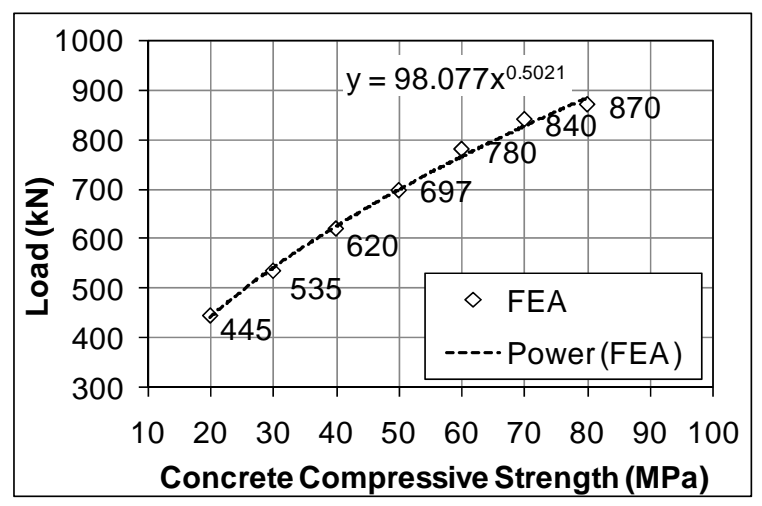

(b) Punching capacity.

Figure 9. Effect of concrete compressive strength. 
The model shown in Figs. 2 and 3 was used for the five slabs. For all cases, the slab thickness was divided into three layers. The thickness of the layers was selected to produce a finer mesh in the compression zone near the top surface of the slab to increase the accuracy of the analysis. A concrete compressive strength of $40 \mathrm{MPa}$ was used for all cases. All other parameters (reinforcement, concrete covers, loading and boundary conditions) were kept the same as that of the GFRP slab.

\subsubsection{Deflection and Cracking Behavior}

The predicted load-deflection curves of the five cases are given in Fig. 10a. It can be noticed that the deflections decreased with increasing deck thickness as a result of the significant increase in the stiffness of the slabs. At the service load level, the maximum predicted deflections were $3.8,2.1,1.48,0.29$ and $0.21 \mathrm{~mm}$ for slabs with thicknesses of 150, 175, 200, 225 and $250 \mathrm{~mm}$, respectively. This indicates that only the slab with the $150 \mathrm{~mm}$ thickness (span/depth $=13.33$ ) has higher deflections than those allowed by the AASHTO code (span/800 $=2.5 \mathrm{~mm}$ ) (AASHTO 1996). The predicted cracking load was $75 \mathrm{kN}$ for the $150 \mathrm{~mm}$ thick deck slab. The cracking load increased by about $13 \%, 47 \%, 80 \%$ and $127 \%$ when the slab thickness increased to 175, 200, 225 and $250 \mathrm{~mm}$, respectively.

\subsubsection{Reinforcement Strains}

The predicted load-maximum bottom transverse reinforcement strains behavior using different slab thicknesses is shown in Fig. 10b. It can be observed that the reinforcement strains decreased by increasing the slab thickness. At the factored design load, the maximum predicted reinforcement strains were 3,145 , 2,765, 2,485, 2,050 and 1,259 micro-strains (about 24 to $10 \%$ of the ultimate strain of the GFRP bars) for slabs of 150, 175, 200, 225 and $250 \mathrm{~mm}$ thickness, respectively. This indicated that, at the factored load, the maximum bottom transverse reinforcement strains of the slab with the $150 \mathrm{~mm}$ thickness decreased by about 12, 21, 34 and $60 \%$ by increasing the slab thickness to 175, 200, 225 and $250 \mathrm{~mm}$, respectively. The maximum predicted reinforcement strains at the failure load of each slab were very close and ranged between 6,890 and 7,410 micro-strains (about $55 \%$ of the ultimate strain of the GFRP bars). This indicates that all the slabs reached the same level of strains at failure regardless of the slab thicknesses.

\subsubsection{Failure Load}

The effect of slab thickness on the punching shear capacity is illustrated in Fig. 10c. As the slab thickness increased, both the effective depth and the critical perimeter increased, resulting in higher failure loads. The failure load was $476 \mathrm{kN}$ in the $150 \mathrm{~mm}$ thick. It can be observed that the values of the failure load increased by about $13 \%, 30 \%, 53 \%$ and $71 \%$ when the slab thickness increased to 175, 200, 225 and $250 \mathrm{~mm}$, respectively. The failure loads increased almost linearly with respect to the slab thickness as shown by the trend line in Fig. 10c.

\subsection{Span-to Depth Ratio}

The punching shear behavior of restrained concrete deck slabs reinforced with steel has been studied by many researchers (Graddy et al. 2002; Fang et al. 1990; Hewitt and Batchelor 1975). They concluded that punching shear failure is the mode of failure of restrained bridge deck slabs with a span/depth ratio of 9 to 15 . In order to investigate the effect of span/depth ratio on the overall behavior and failure mode of FRP-RC bridge deck slabs, six span/depth ratios were investigated $(8,10,12,14,16$ and 18). All the slabs had the same depth of $200 \mathrm{~mm}$. The investigated span/depth ratios provided spans ranging between 1,600 and $3,800 \mathrm{~mm}$. A concrete compressive strength of $40 \mathrm{MPa}$ was used for all cases. All other parameters (dimensions, reinforcement, concrete covers, loading and boundary conditions) were kept the same as that of slab GFRP.

\subsubsection{Deflection and Cracking Behavior}

The predicted load-deflection curves of the six cases are shown in Fig. 11a. Increasing the span-to-depth ratio decreased the cracking loads of the deck slabs. The predicted cracking load was $125 \mathrm{kN}$ for the deck slab with a span-todepth ratio of eight. The cracking load decreased by about $12,20,32,40$ and $46 \%$ when the spanto-depth ratio increased to $10,12,14,16$ and 18 , respectively. 


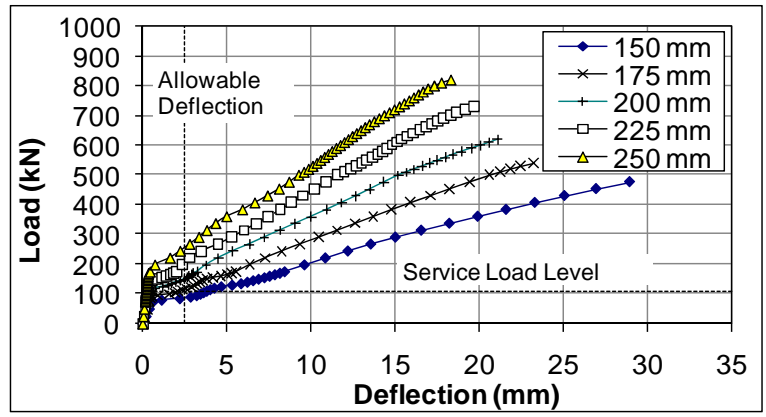

(a) Load-maximum deflection.

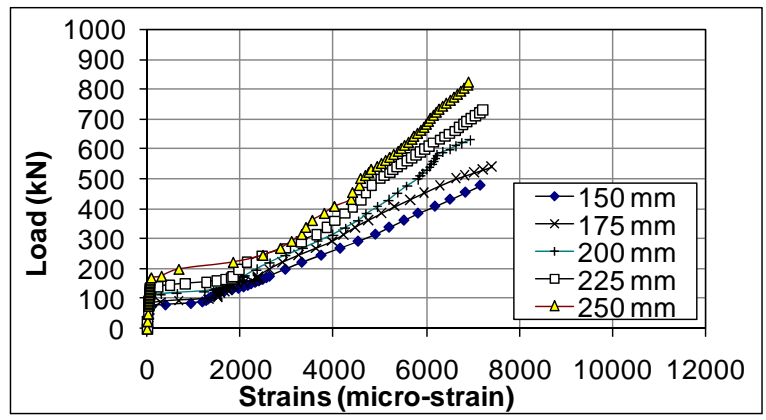

(b) Load-maximum reinforcement strains.

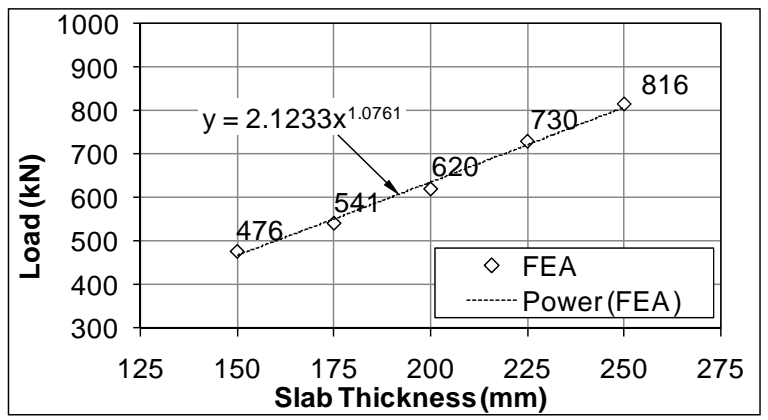

(c) Punching capacity.

Figure 10. Effect of slab thickness.

It can be also noticed that the deflections increased by increasing the span/depth ratio as a result of the increase in the bending moments applied on the deck slabs.

\subsubsection{Reinforcement Strains}

The predicted load-maximum bottom transverse reinforcement strains behavior using different span-to-depth ratios is shown in Fig. 11b. The reinforcement strains increased as the span/depth ratio increased. At the factored design load, the maximum predicted reinforcement strains were 1,795, 2,485, 2,665, $3,745,4,025$ and 4,395 micro-strains (about 13\% to $32 \%$ of the ultimate strain of GFRP bars) for slabs with span/depth ratios of $8,10,12,14,16$ and 18, respectively, which corresponded to spans of 1.6, 2, 2.4, 2.8, 3.2 and $3.6 \mathrm{~m}$, respectively.

This indicates that, at the factored design load, increasing the span-to-depth ratio by 25 , $50,75,100$ and $125 \%$ (from 10 to 18) increased the bottom transverse reinforcement strains by about 38, 48, 108, 125 and $144 \%$, respectively. The maximum predicted reinforcement strains at failure were 5,220, 6,925, 7,783, 8,504, 9,499 and 9,741 micro-strains, respectively. These values are about 40 to $75 \%$ of the ultimate strain of the GFRP bars.

\subsubsection{Failure Load}

The effect of span/depth ratio on the punching shear capacity is illustrated in Fig. 11c. As the span/depth ratio increased, the bending moments increase resulting in higher concrete compressive strains and lower failure loads. All the slabs failed due to concrete crushing, leading to punching shear failure. The failure load was found to be $700 \mathrm{kN}$ of the slab with a span/depth ratio of eight. It was observed that the values of the failure load decreased by about $11.5 \%, 20 \%, 25 \%, 30 \%$ and $36 \%$ when the spanto-depth ratio increased to $10,12,14,16$ and 18, respectively. Figure 11c shows that the failure loads did not decrease linearly with respect to the span/depth ratio. This may be attributed to the arching action in bridge deck slabs. For lower span-to depth ratios, the induced in-plane compressive membrane forces are higher, leading to concrete confinement. Consequently, the failure loads increased.

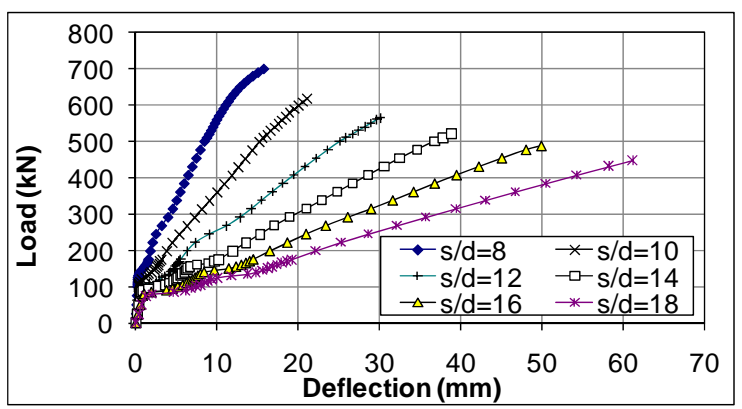

(a) Load-maximum deflection. 


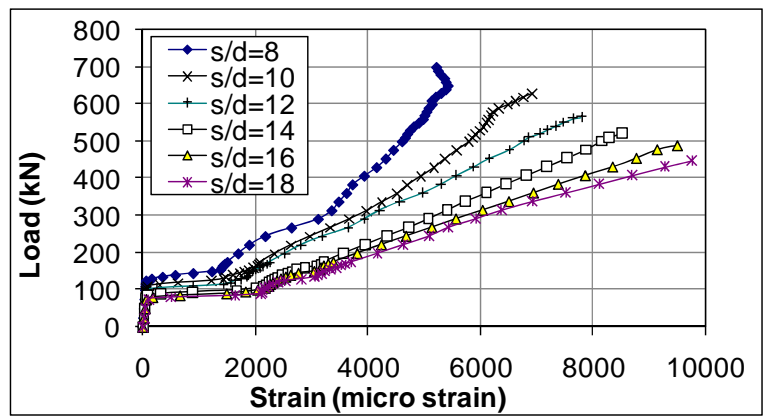

(b) Load-maximum reinforcement strains.

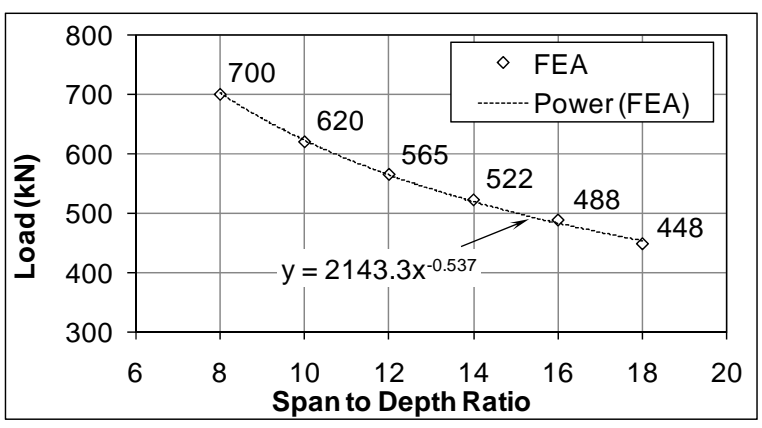

(c) Punching capacity.

Figure 11. Effect of span to depth ratio.

\section{Conclusions}

This paper presents a non-linear FEA investigation of FRP-RC bridge deck slabs to study their behavior at different load levels. The validity and accuracy of the FEA were verified against experimental test results conducted by the author. Using the FEA, the effect of some key parameters that influence the behavior of FRP-RC bridge deck slabs was investigated. These parameters included the FRP reinforcement ratio, concrete compressive strength, slab thickness and span-to-depth ratio.

Based on the results of this study, the following points can be concluded:

1. The FE analysis conducted using the ANACAP program was capable of predicting the behavior, punching capacity and mode of failure of FRP-RC bridge deck slabs.

2. The bottom main reinforcement had an insignificant effect on the punching strength of restrained bridge deck slabs; however, it had a small effect on the deflection behavior.

3. The top reinforcement had a negligible effect on the deflection behavior, strains and punching capacity of deck slabs.

4. The concrete compressive strength, slab thickness and span-to-depth ratio had a significant effect on the overall behaviour of FRP-reinforced bridge deck slabs.

5. Increasing the concrete strength decreased deflections and increased the punching capacity. The FEM proved that the punching capacity is proportional to the square root of the concrete compressive strength, which is in agreement with several design codes.

6. Increasing the slab thickness significantly increased the punching capacity and decreased the deflections and reinforcement strains. At the factored load, the maximum bottom transverse reinforcement strains of slab with a $150 \mathrm{~mm}$ thickness decreased by about $12,21,34$ and $60 \%$ by increasing the slab thickness to 175, 200, 225 and $250 \mathrm{~mm}$, respectively. The failure loads increased almost linearly with respect to the deck slab thicknesses.

7. Increasing the span-to-depth ratio from 8 to 18 significantly decreased the punching capacity and increased the deflections and reinforcement strains. At the factored design load, increasing the span-to-depth ratio by $25,50,75,100$ and $125 \%$ (from 8 to 10, 12, 14, 16 and 18) increased the bottom transverse reinforcement strains to by about $38,48,108$, 125 and $144 \%$, respectively.

\section{Acknowledgment}

Thanks are due to the anonymous referees for their valuable comments, which improved the quality of the paper.

\section{References}

AASHTO (1996), Standard specifications for highway bridges. American Association of State Highway and Transportation Officials, Washington D.C.

ACI 440.1R-06 (2006), Guide for the design and construction of concrete reinforced with FRP 
bars. American Concrete Institute, Farmington Hills, Michigan, USA.

ACI 318-08 (2008), Building code requirements for reinforced concrete. American Concrete Institute, Farmington Hills, Michigan 427.

Alsayed S, Al-Salloum Y, Almusallam T, ElGamal S, Aqel M (2012), Performance of glass fiber reinforced polymer bars under elevated temperatures. Composites Part B 43:22652271.

Bouguerra K, Ahmed E, El-Gamal S, Benmokrane B (2011), Testing of full-scale concrete bridge deck slabs reinforced with fiber reinforced polymer (FRP) bars. Construction and Building Materials Journal 25:3956-3965.

British Standards Institution (1997), Structural use of concrete, BS 8110: Part 1- code of practice for design and construction, London.

CSA-A23.3 M-94 (1994), Design of concrete structures for buildings. Canadian Standards Association, Rexdale, Ontario.

CAN/CSA-S6 (2006), Canadian Highway Bridge Design Code. CHBDC, Canadian Standard Association, Rexdale, Ontario, Canada.

El-Gamal S, El-Salakawy E, Benmokrane B (2004), Behaviour of FRP reinforced concrete bridge decks under concentrated loads. Proceedings of the $4^{\text {th }}$ International Conference on Advanced Composite Materials in Bridges and Structures, Calgary, Alberta, Canada.

El-Gamal S (2005a), Behavior of restrained concrete bridge deck slabs reinforced with reinforcing bars under concentrated load. Ph.D. Thesis, Sherbrooke (Quebec): Department of Civil Engineering, Université de Sherbrooke, Canada.

El-Gamal S, El-Salakawy E, Benmokrane B (2005a), Behavior of concrete bridge deck slabs reinforced with FRP bars under concentrated loads. ACI Structural Journal 102(5):727-735.

El-Gamal S, El-Salakawy E, Benmokrane B (2005b), A new punching shear equation for two-way concrete slabs reinforced with FRP bars. ACI Special Publication SP-230(50):877894.
El-Gamal S, El-Salakawy E, Benmokrane B (2007), Influence of reinforcement on the behavior of concrete bridge deck slabs reinforced with FRP bars. ASCE, Journal of Composites for Constructions 11(5):449-458.

Fang I, Worley J, Burns N, Klingner R (1990), Behavior of isotropic reinforced concrete bridge decks on steel girders. Journal of Composites of Construction, ASCE 116(3): 659-678.

Graddy J, Kim J, Whitt J, Burns N, Klingner R (2002), Punching shear behavior of bridge decks under fatigue loading. ACI structural Journal 99(3):257-266.

Hassan T, Rizkalla S, Abdelrahman A, Rochelle R (2004), FRP bars for concrete bridge decks. Proceedings of the 4th International Conference on Advanced Composite Materials in Bridges and Structures, Calgary, Alberta, Canada.

Hewitt B, Batchelor B (1975), Punching shear strength of restrained slabs. Journal of Structural Division, ASCE 101(ST9):18371853.

James, R.G.(2004), ANACAP Concrete Analysis Program Theory Manual, Version 3.0, Anatech Corporation, San Diego, CA, 2004.

Japan Society of Civil Engineers, JSCE (1997), Recommendation for design and construction of concrete structures using continuous fibre reinforcing materials. Concrete Engineering Series 23, Edited by A Machida.

Kinnunen S, Nylander H (1960), +. Transactions of the Royal Institute of Technology, Stockholm, Sweden. Norway 112.

Marzouk H, Hussien A (1991), Punching shear analysis of restrained high strength concrete slabs. Canadian Journal of Civil Engineering 18:954-963.

Mohamed K, Rizkalla S (1999), Behavior of concrete bridge decks reinforced with FRP. Technical report, ISIS Canada, University of Manitoba, Manitoba, Canada.

Mufti A, Newhook J (1998), Punching shear strength of restrained concrete bridge deck slabs. ACI Structural Journal 95:(4):375-381. 